\title{
HETEROSIS EXPRESSION IN CROSSES BETWEEN MAIZE POPULATIONS: EAR YIELD
}

\author{
Ricardo Machado da Silva; José Branco de Miranda Filho* \\ USP/ESALQ - Depto. de Genética, C.P. 83 - 13418-900 - Piracicaba, SP - Brasil. \\ *Corresponding author <jbmirand@esalq.usp.br
}

\begin{abstract}
The phenomenon of heterosis has been exploited extensively in maize (Zea mays L.) breeding. The objective of this study was to evaluate the genetic potential of ten maize populations for ear yield following the diallel mating scheme. Six parental populations were obtained through phenotypic selection of openpollinated ears in Rio Verde, GO, Brazil, (GO populations) and four parental populations were synthesized in Piracicaba, SP, Brazil (GN populations): GO-D (DENTADO), GO- F (FLINT), GO-A (AMARELO), GO-B (BRANCO), GO-L (LONGO), GO-G (GROSSO), GN-01, GN-02, GN-03 and GN-04. Experiments were carried out in three environments: Anhembi (SP) and Rio Verde (GO) in 1998/99 (normal season crop) and Piracicaba (SP) in 1999 (off-season crop). All experiments were in completely randomized blocks with six replications. Analysis of variance grouped over environments showed high significance for heterosis and its components, although mid-parent heterosis and average heterosis were of low expression. The interaction treatments $\mathrm{x}$ environments was not significant. Total mid-parent heterosis effects ranged from de $-4.3 \%$ to $17.3 \%$ with an average heterosis of $3.37 \%$. Population with the highest yield $\left(7.4 \mathrm{tha}^{-1}\right)$ and with the highest effect of population $\left(v_{i}=0.746\right)$ was GN-03, while the highest yielding cross was GO-B x GN-03 with 7,567 $\mathrm{t} \mathrm{ha}^{-1}$. The highest specific heterosis effect $\left(\mathrm{s}_{\mathrm{ii}}=0.547\right)$ was observed in the cross GO-B x GN-03.

Key words: Zea mays, diallel cross, combining ability
\end{abstract}

\section{HETEROSE EM CRUZAMENTOS ENTRE POPULAÇÕES DE MILHO: PESO DE ESPIGAS}

\begin{abstract}
RESUMO: O fenômeno da heterose vem sendo amplamente explorado no melhoramento do milho. O objetivo do presente estudo foi avaliar o potencial genético de dez populações de milho (Zea mays L.) em esquema de cruzamento dialélico para a variável peso de espigas. Seis populações parentais foram obtidas por seleção fenotípica entre espigas de polinização aberta em Rio Verde, GO (populações GO) e quatro populações parentais foram sintetizadas em Piracicaba, SP: (populações GN): GO-DENTADO, GO-FLINT, GO-AMARELO, GOBRANCO, GO-LONGO, GO-GROSSO, GN-01, GN-02, GN-03 e GN-04; as seis primeiras são simbolizadas por GO-D, GO-F, GO-A, GO-B, GO-L e GO-G, respectivamente. Os experimentos foram conduzidos em três ambientes: Anhembi (SP) e Rio Verde (GO) no ano de 1998/99 e Piracicaba (SP) em cultura de safrinha em 1999. Os experimentos foram conduzidos segundo o delineamento de blocos completos casualizados com seis repetições. Na análise conjunta entre ambientes, observou-se que os efeitos de heterose e seus componentes foram altamente significativos, apesar de a heterose individual e heterose média em relação à média dos pais terem sido pouco expressivas. Não foram significativos os efeitos da interação tratamentos x ambientes. Os efeitos de heterose total variaram de $-4,3 \%$ a 17,3\% em relação à média dos pais, com heterose média de $3,37 \%$. A população mais produtiva $\left(7,364 \mathrm{t} \mathrm{ha}^{-1}\right)$ e com maior valor do efeito de população $\left(v_{\mathrm{i}}=0,746\right)$ foi GN-3, enquanto que o híbrido mais produtivo foi GO-B x GN-03 com 7,567 t ha ${ }^{-1}$. O maior efeito de heterose específica $\left(\mathrm{s}_{\mathrm{ii},}=0,547\right)$ foi observada no híbrido GO-B x GN-03.

Palavras-chave: Zea mays, cruzamento dialélico, capacidade de combinação
\end{abstract}

\section{INTRODUCTION}

Basic knowledge on the genetic potential of base populations, either per se or in crosses, are important information in breeding programs for the development of outstanding cultivars. The diallel mating scheme has been widely used to provide information on the performance of parental populations and their heterotic pattern in crosses (Hallauer \& Miranda Filho, 1995). Diallel crosses also allow the identification of heterotic groups and the prediction of the performance of new populations (composites) derived from population crosses (Miranda Filho, 1974; Miranda Filho \& Vencovsky, 1984; Miranda Filho \& Chaves, 1991; Hallauer \& Miranda Filho, 1995).

The term heterosis was coined by Shull in 1912 (Shull, 1952); it is a quantitative measure of the superiority of a hybrid over its parents. It has been widely used in maize breeding programs for the identification of genetically divergent populations as base for the development of inbred lines to be used in hybrid crosses 
(Hallauer, 1990). Hallauer \& Miranda Filho (1995) reported that on a survey of 1394 variety crosses, the midparent heterosis varied from $4.2 \%$ to $72.0 \%$, averaging $19.5 \%$. High heterosis estimates have been observed for yield in crosses between races of maize. Paterniani \& Lonnquist (1963) reported heterosis varying from $-11.0 \%$ to $101.0 \%$ in crosses among 12 Brazilian races of maize. Wellhausen (1965) observed heterosis of the order of $64.0 \%$ in crosses between Mexican races. Paterniani (1968) also detected high heterosis expression, varying from $8.8 \%$ to $136.3 \%$ in interracial crosses. Relatively high heterosis expression was also reported by Castro et al. (1968), Crossa et al. (1990a) and Paterniani (1980), with average heterosis of $24.8 \%, 39.0 \%$, and $18.6 \%$, respectively.

Miranda Filho \& Vencovsky (1984) estimated heterosis for yield in two sets of varieties; average heterosis was higher $(23.5 \%)$ in set-I (seven short plant and narrow base populations) than in set-II (set-I plus two broad base composites named as FC- FLINT COMPOSITE and DC- DENT COMPOSITE), where the average heterosis was $16.7 \%$. The cross FC x DC showed a small, negative heterosis of $-0.5 \%$.

The expression of heterosis depends on the level of dominance controlling the trait (Falconer \& Mackay, 1996). Therefore, grain yield in maize is expected to exhibit heterosis as a consequence of partial to complete dominance of genes controlling the trait (Hallauer \& Miranda Filho, 1995). On the other hand, the expression of heterosis also depends on the level of genetic divergence between parents; i.e., differences in allele frequencies are necessary for the expression of heterosis. For that reason, expression of heterosis is expected to be lower in crosses between broad base open-pollinated populations (Miranda Filho, 1999). As a matter of fact, several reports on crosses between broad base populations have indicated a much lower expression of heterosis; average midparent heterosis of the order of $6.05 \%, 7.38 \%, 8.5 \%$ and $8.8 \%$ for yield in maize were reported by Beck et al. (1990), Crossa et al. (1990b), Vasal et al. (1992), and Rezende \& Souza Jr. (2000), respectively. The present work aims to evaluate the expression of heterosis in crosses of ten open-pollinated and broad base populations, following the diallel mating scheme.

\section{MATERIAL AND METHODS}

Six broad base populations were developed through phenotypic selection of 52 open-pollinated ears from an experimental area with several and different experiments in Rio Verde (GO). The sample of 52 ears was divided in two groups: 27 flint type ears and 25 dent type ears; from the same set of 52 ears, two other samples were taken: 20 long ears and 17 thick ears; finally the set of
52 ears was again divided in two samples: 40 yellow endosperm ears and 12 ears segregating for white endosperm. The six samples were designated as: GO-D (DENTADO - dent type), GO- F (FLINT: flint type), GOA (AMARELO - yellow endosperm), GO-B (BRANCO - white endosperm), GO-L (LONGO: long ears), GO-G (GROSSO - thick ears) (Silva, 2001). The six GO populations were then recombined through hand pollination of plants within each population with a sample of pollen of the same population. Six samples of seeds representing each population were sown in isolated blocks under open pollination in Rio Verde (GO), which originated the six populations after two generations of recombination. The origin of the six populations, as described above, leads to the conclusion that pairs of populations (GO-D vs. GO-F, GO-L vs. GO.G, GO-B vs. GO-A) exhibit some level of genetic relationship because their original parental ears were pollinated with pollen of the same origin. On the other hand, the genetic relationship between populations of different pairs (e.g., GO-D and GO-L) may be higher because they may have some parental ears in common, which would result in a relationship from the female parent. The exact genetic parentage between pairs of populations could not be estimated on the basis of the available information.

Other four populations are composites obtained in the Department of Genetics (USP/ESALQ) by intercrossing open-pollinated populations of several origins which were designated: GN-01, GN-02, GN-03, and GN04 (Nass \& Miranda Filho, 1999). The ten populations were crossed following the complete diallel mating scheme.

Parental populations (10) and their crosses (45) were evaluated in three environments: Anhembi, SP, Bra-

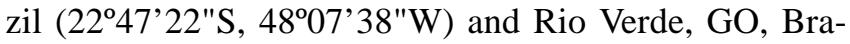
zil (17\%47'53"S, 5055'41"W) in 1998/99 (normal season crop) and Piracicaba, SP Brazil (22\%43'31"S, $47^{\circ} 38^{\prime} 57^{\prime \prime} \mathrm{W}$ ) in 1999 (off-season crop). Trials were set in completely randomized blocks design $(n=6)$. The hybrid G-85 (Novartis Seeds) was used as check, intercalated after each ten plots in all replications. Plots consisted of double rows with $4 \mathrm{~m}$ and 20 plants per row after thinning. Fertilization and cultural practices were carried out according to recommendation for each environment. Several traits were measured but, for the purpose of this work, only ear yield was analyzed. The total ear weight in the plot was corrected for stand variation and adjustment was for each plot with expected stand of 40 plants per plot, following the procedure suggested by Miranda Filho, (op. cit. Vencovsky \& Barriga, 1992) based on the formula: $\mathrm{Y}_{\mathrm{c}}=\mathrm{Y}_{0}+\mathrm{b}(\mathrm{N}-\mathrm{S})$, for each plot; $\mathrm{Y}_{\mathrm{c}}$ is the adjusted yield, $\mathrm{Y}_{0}$ is the original plot yield, $\mathrm{b}$ is the regression coefficient of yield on stand variation, $\mathrm{N}$ is the expected or ideal stand (40 plants) and $\mathrm{S}$ is the observed stand. 
The analysis of the diallel table followed the model of Gardner \& Eberhart (1966): $Y_{\mathrm{ii}},=\mu+\frac{1}{2}$ $\left(v_{i}+v_{i,}\right)+\theta\left(\bar{h}+h_{i}+h_{i},+s_{i i j}\right)+\bar{e}_{i i \prime}$, where $Y_{i i j}$, represents the mean yield (over six replications) of a parent population ( $\left.i=i^{\prime}\right)$ or a population cross $\left(i<i^{\prime}\right)$; $m$ is the mean of all parental populations; $\mathrm{v}_{\mathrm{i}}$ or $\mathrm{v}_{\mathrm{i}}$, are the variety or population effect; $\overline{\mathrm{h}}$ is the average heterosis of all crosses; $h_{i}$ or $h_{i}$, is the variety or population heterosis effect; $\mathrm{s}_{\mathrm{ii}}$ is the specific heterosis effect; $\overline{\mathrm{e}}_{\mathrm{ii}}$ is the error term associated with the observed mean; and $\theta=0$ for parental populations and $\theta=1$ for crosses.

\section{RESULTS AND DISCUSSION}

Means of ear yield for parental populations, population crosses and check are shown for the three environments (Table 1). Large effects of environments were observed and check means were always larger than the di- allel means; check means were 5.599 in Anhembi, 9.475 in Rio Verde and $7.733 \mathrm{t} \mathrm{ha}^{-1}$ in Piracicaba. The mean of the parental populations is an estimate of $\mu$ in the diallel model; estimates $(\hat{\mu})$ were $4.934,7.890$ and $7.030 \mathrm{t}$, respectively, averaging $6.618 \mathrm{t} \mathrm{ha}^{-1}$. Populations GN-04 and GN-03 had higher yield than the check in Anhembi and Piracicaba, respectively, but no population exceeded the check in the combined analysis over environments. Number of crosses that yielded more than the check were three (GO-L x GN-01, GO-B x GN-03 and GO-B x GN-04) in Anhembi (SP) and three (GO-L x GN-04, GO-B x GN03 and GN-02 x GN-04) in Piracicaba (SP). No cross exceeded the check mean in Rio Verde (GO) and in the combined analysis in which the best two crosses (GO-B x GN03 and GN-02 x GN-04) and parental population GN-03 yielded $99.5 \%, 98.0 \%$ and $96.9 \%$, respectively, in relation to the check. Also, in the combined analysis, populations and crosses, on the average, yielded $87.1 \%$ and

Table 1 - Observed yield means of parental population and their crosses in three environments.

\begin{tabular}{|c|c|c|c|c|}
\hline Population & $\begin{array}{c}\text { Anhembi (SP) } \\
(1998 / 99)^{1}\end{array}$ & $\begin{array}{c}\text { Rio Verde (GO) } \\
(1998 / 99)^{1}\end{array}$ & $\begin{array}{c}\text { Piracicaba (SP) } \\
(1999)^{2} \\
\end{array}$ & Combined \\
\hline & 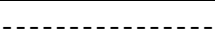 & (n-........ & & \\
\hline GO-G & 5.069 & 7.617 & 7.232 & 6.639 \\
\hline GO-L & 4.355 & 7.960 & 6.739 & 6.351 \\
\hline GO-D & 4.937 & 8.328 & 7.072 & 6.779 \\
\hline GO-F & 5.129 & 7.991 & 7.109 & 6.743 \\
\hline GO-B & 4.318 & 7.148 & 7.081 & 6.182 \\
\hline GO-A & 5.023 & 7.458 & 6.413 & 6.298 \\
\hline GN-01 & 4.125 & 7.646 & 6.173 & 5.981 \\
\hline GN-02 & 5.250 & 8.146 & 6.920 & 6.772 \\
\hline GN-03 & 5.492 & 8.619 & 7.981 & 7.364 \\
\hline GN-04 & 5.641 & 7.987 & 7.583 & 7.070 \\
\hline GO-G x GO-L & 4.372 & 7.762 & 7.179 & 6.438 \\
\hline GO-G x GO-D & 4.672 & 7.863 & 7.139 & 6.558 \\
\hline GO-G x GO-F & 4.750 & 7.871 & 6.889 & 6.503 \\
\hline GO-G x GO-B & 4.228 & 8.165 & 7.156 & 6.516 \\
\hline GO-G x GO-A & 4.910 & 7.403 & 7.108 & 6.474 \\
\hline GO-G x GN-01 & 5.223 & 8.637 & 7.012 & 6.957 \\
\hline GO-G x GN-02 & 5.597 & 7.927 & 6.766 & 6.763 \\
\hline GO-G x GN-03 & 5.222 & 7.918 & 6.953 & 6.698 \\
\hline GO-G x GN-04 & 5.571 & 8.799 & 7.009 & 7.126 \\
\hline GO-L x GO-D & 5.266 & 7.984 & 7.107 & 6.786 \\
\hline GO-L x GO-F & 4.555 & 7.971 & 6.895 & 6.474 \\
\hline GO-L x GO-B & 4.834 & 8.253 & 6.778 & 6.622 \\
\hline GO-L x GO-A & 5.305 & 8.308 & 7.269 & 6.961 \\
\hline GO-L x GN-01 & 5.789 & 8.196 & 7.709 & 7.231 \\
\hline GO-L x GN-02 & 5.315 & 8.680 & 7.180 & 7.058 \\
\hline GO-L x GN-03 & 5.077 & 8.517 & 7.211 & 6.935 \\
\hline GO-L x GN-04 & 4.809 & 8.181 & 7.912 & 6.967 \\
\hline GO-D x GO-F & 4.969 & 8.616 & 6.441 & 6.675 \\
\hline GO-D x GO-B & 4.947 & 7.786 & 7.336 & 6.690 \\
\hline GO-D x GO-A & 4.856 & 8.206 & 6.848 & 6.637 \\
\hline GO-D x GN-01 & 4.848 & 7.868 & 6.845 & 6.520 \\
\hline
\end{tabular}


Table 1 - Continuation.

\begin{tabular}{|c|c|c|c|c|}
\hline Population & $\begin{array}{c}\text { Anhembi (SP) } \\
(1998 / 99)^{1}\end{array}$ & $\begin{array}{l}\text { Rio Verde (GO) } \\
\quad(1998 / 99)^{1}\end{array}$ & $\begin{array}{c}\text { Piracicaba (SP) } \\
(1999)^{2}\end{array}$ & Combined \\
\hline \multicolumn{5}{|c|}{-1} \\
\hline GO-D x GN-02 & 5.466 & 8.301 & 7.592 & 7.120 \\
\hline GO-D x GN-03 & 5.290 & 8.494 & 7.107 & 6.964 \\
\hline GO-D x GN-04 & 5.408 & 8.143 & 7.610 & 7.054 \\
\hline GO-F x GO-B & 5.264 & 8.227 & 7.539 & 7.010 \\
\hline GO-F x GO-A & 4.667 & 8.116 & 7.158 & 6.647 \\
\hline GO-F x GN-01 & 4.876 & 8.554 & 6.881 & 6.770 \\
\hline GO-F x GN-02 & 5.277 & 8.263 & 7.620 & 7.053 \\
\hline GO-F x GN-03 & 5.064 & 8.505 & 7.076 & 6.882 \\
\hline GO-F x GN-04 & 5.091 & 8.521 & 7.582 & 7.065 \\
\hline GO-B x GO-A & 4.883 & 8.228 & 7.552 & 6.888 \\
\hline GO-B x GN-01 & 4.716 & 8.364 & 7.010 & 6.697 \\
\hline GO-B x GN-02 & 5.138 & 8.556 & 7.572 & 7.089 \\
\hline GO-B x GN-03 & 5.753 & 8.797 & 8.150 & 7.567 \\
\hline GO-B x GN-04 & 5.652 & 8.148 & 6.413 & 6.738 \\
\hline GO-A x GN-01 & 5.061 & 7.868 & 7.042 & 6.657 \\
\hline GO-A x GN-02 & 5.176 & 8.795 & 7.653 & 7.208 \\
\hline GO-A x GN-03 & 4.922 & 8.505 & 7.302 & 6.910 \\
\hline GO-A x GN-04 & 4.421 & 8.418 & 7.206 & 6.682 \\
\hline $\mathrm{GN}-01 \times \mathrm{GN}-02$ & 5.039 & 8.613 & 7.254 & 6.969 \\
\hline GN-01 $\times$ GN-03 & 4.932 & 7.890 & 7.101 & 6.641 \\
\hline GN-01 x GN-04 & 5.259 & 8.309 & 7.148 & 6.905 \\
\hline GN-02 $\times$ GN-03 & 5.574 & 8.564 & 7.555 & 7.231 \\
\hline $\mathrm{GN}-02 \times \mathrm{GN}-04$ & 5.566 & 8.766 & 8.027 & 7.453 \\
\hline GN-03 $\times$ GN-04 & 5.392 & 8.549 & 7.588 & 7.176 \\
\hline Check mean & 5.599 & 9.475 & 7.733 & 7.602 \\
\hline Diallel mean & $5.061[90.4]^{3}$ & $8.206[86.6]^{3}$ & $7.196[93.1]^{3}$ & $6.821[89.7]^{3}$ \\
\hline Populations (P) & $4.934[88.1]^{3}$ & $7.890[83.3]^{3}$ & $7.030[90.9]^{3}$ & $6.618[87.1]^{3}$ \\
\hline Crosses (C) & $5.089[90.9]^{3}$ & $8.276[87.3]^{3}$ & $7.233[93.5]^{3}$ & $6.866[90.3]^{3}$ \\
\hline Difference: C-P & $0.155[3.1]^{4}$ & $0.386[4.9]^{4}$ & $0.203[2.9]^{4}$ & $0.248[3.7]^{4}$ \\
\hline $\mathrm{CV} \%$ & 12.8 & 7.9 & 10.1 & -- \\
\hline
\end{tabular}

${ }^{1}$ Normal season planting; ${ }^{2}$ off-season planting; ${ }^{3}$ in percent of the check mean; ${ }^{4}$ in percent of parental population mean; $\mathrm{CV} \%$ : experimental coefficient of variation.

$90.3 \%$, respectively, in relation to the hybrid check. The cross GN-03 x GN-04 ranked in the seventh position yielding $94.4 \%$ in relation to the check hybrid. Good performance of this cross was expected because its parental populations were synthesized using prediction procedures to develop an outstanding heterotic group (Nass \& Miranda Filho, 1999). Other outstanding crosses also involved $\mathrm{GN}-03$ and $\mathrm{GN}-04$ as parents.

The difference between parents and crosses is an estimate of the average heterosis of all crosses, which varied from $2.9 \%$ to $4.9 \%$ over environments, averaging $3.7 \%$ (Table 1). A preliminary analysis of variance with the original data (not shown) was performed for each environment to estimate the pooled error mean square, which was divided by the number of replications in the analysis following the diallel model with population means (Table 2). The average ear yield was $6.821 \mathrm{t} \mathrm{ha}^{-1}$. Treatment $\mathrm{x}$ environment interaction was non-significant in the analysis of vari- ance over environments. All other sources of variation were highly significant $(P<0.01)$. The mean square for the difference among populations was four times larger than for heterosis. Average heterosis seemed to be the most important component of the total heterosis and population heterosis presented a mean square 2.3 times greater than the specific heterosis. Miranda Filho \& Vencovsky (1984) observed non significance for specific heterosis in a diallel cross among open pollinated varieties but the $\mathrm{F}$ value $(\mathrm{F}$ test) was similar to $\mathrm{F}$ value for specific heterosis herein obtained. Significance for specific combining ability, which has the same meaning as specific heterosis, also was reported by Crossa et al. (1987), Crossa et al. (1990a), Pandey et al. (1994), and Pérez-Velásquez et al. (1995).

The most promising populations, as based on their performance per se ( $\mathrm{v}_{\mathrm{i}}$ effects) were GN-03 and GN04 , with estimates of 0.746 and 0.452 , respectively (Table 3.) The smallest estimate $(-0.436)$ was for GO-B. Nass 
\& Miranda Filho (1999) also observed the outstanding performance of the populations GN-03 and GN-04, indicating them to be used as base for intrapopulation recurrent selection. The authors also observed high genetic variability in both $\mathrm{GN}-03$ and $\mathrm{GN}-04$.

The significant effect of population heterosis $\left(h_{i}\right)$ is a consequence of the genetic divergence of each population with the whole set of populations. The most heterotic populations were GN-01 (0.263) and GO-B (0.221); and the most negative estimate $(-0.230)$ was for GO-G. General combining ability $\left(\mathrm{g}_{\mathrm{i}}\right)$ is a function of both $\mathrm{v}_{\mathrm{i}}$ and $\mathrm{h}_{\mathrm{i}}$, and varied from -0.220 (GO-G) to 0.269 (GN-02); the next higher $\mathrm{g}_{\mathrm{i}}$ estimates are $0.171(\mathrm{GN}-04)$ and 0.151 (GN-03), which result from their high $\mathrm{v}_{\mathrm{i}}$ estimates since $h_{i}$ estimates are negative for both GN-03 and GN-04.

Specific heterosis effects varied from -0.321 (GN-01 x GN-03) to 0.547 (GO-B x GN-03). Despite the apparently low importance of specific heterosis as source of variation, their effects can contribute expressively to the performance of outstanding crosses. Hoegemeyer \&

Table 2 - Analysis of variance for ear yield in three environments following the model of Gardner $\&$ Eberhart (1966) for diallel crosses.

\begin{tabular}{lrr}
\hline Sources of variation & d.f. & \multicolumn{1}{c}{ M.S. } \\
\hline Environments & 2 & $141.8331 * *$ \\
Treatments & 54 & $0.2908 * *$ \\
$\quad$ Populations & 9 & $0.7834 * *$ \\
$\quad$ Heterosis & 45 & $0.1923 * *$ \\
$\quad$ Average heterosis & 1 & $1.5065^{*} *$ \\
$\quad$ Population heterosis & 9 & $0.2918 * *$ \\
$\quad$ Specific heterosis & 35 & $0.1291 * *$ \\
Treatments x Environments & 108 & $0.0876^{\text {ns }}$ \\
Pooled error* & 810 & 0.0765 \\
\hline Individual mean squares from original data were divided by the \\
number of replications (6) within each environment.
\end{tabular}

Hallauer (1976) found that specifically mated crosses (diagonal in their $4 \times 4$ mating scheme) yielded more than nonspecific crosses, indiating that specific combining ability $\left(s_{i j}\right)$ effects were positive for most of these crosses, thus indicating that $\mathrm{s}_{\mathrm{ij}}$ may contribute to increase the yield of the outstanding hybrids. Stangland et al. (1983) also found highly significant $s_{\mathrm{ij}}$ effects, varying from -0.88 to $1.05 \mathrm{t} \mathrm{ha}^{-1}$, in crosses involving $\mathrm{S}_{2}$ lines from four different populations. Martins \& Miranda Filho (1997) evaluated 120 single crosses between inbred lines from two brachytic type populations and showed that amongst ten highest yielding crosses, nine had positive specific combining ability, varying from $0.060 \mathrm{t} \mathrm{ha}^{-1}$ to $0.416 \mathrm{t} \mathrm{ha}^{-1}$, representing $1.6 \%$ and $10.4 \%$ of the respective hybrid mean. Our results (Table 4$)$ indicate specific heterosis $\left(\mathrm{s}_{\mathrm{ii}}\right)$ varying from -0.321 to $0.547 \mathrm{t} \mathrm{ha}^{-1}$; among the ten highest yielding crosses, seven had positive $s_{i i}$ in the range of 0.084 to $0.547 \mathrm{t} \mathrm{ha}^{-1}$, representing $1.2 \%$ to $7.2 \%$ of the respective hybrid mean. The highest yielding cross (GOB x GN-03) had also the highest estimate of $s_{\mathrm{ii}}$.

Table 3 - Estimate of the effects of populations $\left(v_{i}\right)$, population heterosis $\left(\mathrm{h}_{\mathrm{i}}\right)$ and general combining ability $\left(\mathrm{g}_{\mathrm{i}}\right)$ for ear yield $\left(t \mathrm{ha}^{-1}\right)$ combined over environments.

\begin{tabular}{lccc}
\hline Population & $\hat{\mathrm{v}}_{\mathrm{i}}$ & $\hat{\mathrm{h}}_{\mathrm{i}}$ & $\hat{\mathrm{g}}_{\mathrm{i}}$ \\
\hline GO-GROSSO & 0.021 & -0.230 & -0.220 \\
GO-LONGO & -0.267 & 0.093 & -0.041 \\
GO-DENTADO & 0.161 & -0.179 & -0.099 \\
GO-FLINT & 0.125 & -0.152 & 0.090 \\
GO-BRANCO & -0.436 & 0.221 & 0.003 \\
GO-AMARELO & -0.320 & 0.070 & -0.090 \\
GN-01 & -0.637 & 0.263 & -0.056 \\
GN-02 & 0.154 & 0.192 & 0.269 \\
GN-03 & 0.746 & -0.222 & 0.151 \\
GN-04 & 0.452 & -0.055 & 0.171 \\
\hline
\end{tabular}

Table 4 - Estimates of mid-parent heterosis ${ }^{\psi}$ (above diagonal) and specific heterosis $\left(\mathrm{t} \mathrm{ha}^{-1}\right)$ for ear yield $\left(\mathrm{t}\right.$ ha $\left.{ }^{-1}\right)$ in the diallel cross.

\begin{tabular}{lcccccccccc}
\hline Pop. & GO-G & GO-L & GO-D & GO-F & GO-B & GO-A & GN-01 & GN-02 & GN-03 & GN-04 \\
\hline GO-G & -- & -0.89 & -2.26 & -2.80 & 1.65 & 0.08 & 10.26 & 0.87 & -4.34 & 3.96 \\
GO-L & -0.168 & -- & 3.36 & -1.12 & 5.66 & 10.06 & 17.27 & 7.57 & 1.13 & 3.82 \\
GO-D & 0.010 & 0.059 & -- & -1.27 & 3.22 & 1.50 & 2.19 & 5.08 & -1.53 & 1.86 \\
GO-F & -0.053 & -0.263 & -0.003 & -- & 8.46 & 1.94 & 6.41 & 4.38 & -2.44 & 2.28 \\
GO-B & -0.132 & -0.207 & -0.080 & 0.230 & -- & 10.38 & 10.10 & 9.44 & 11.77 & 1.68 \\
GO-A & -0.081 & 0.226 & -0.039 & -0.038 & 0.110 & -- & 8.43 & 10.30 & 1.15 & -0.04 \\
GN-01 & 0.367 & 0.461 & -0.191 & 0.049 & -0.117 & -0.062 & -- & 9.28 & -0.48 & 5.82 \\
GN-02 & -0.152 & -0.036 & 0.084 & 0.008 & -0.050 & 0.165 & -0.111 & -- & 2.31 & 7.68 \\
GN-03 & -0.100 & -0.042 & 0.045 & -0.046 & 0.547 & -0.016 & -0.321 & -0.055 & -- & -0.57 \\
GN-04 & 0.309 & -0.030 & 0.115 & 0.116 & -0.303 & -0.265 & -0.077 & 0.147 & -0.013 & -- \\
\hline
\end{tabular}

Average heterosis: $\overline{\mathrm{h}}=0.248 \mathrm{t} \mathrm{ha}^{-1}(3.75 \%)$

${ }^{\psi}$ Expressed in percent of the mid-parent 
The total mid-parent heterosis expressed in population crosses (Table 4) varied from $-2.8 \%$ (GO-G x GOF) to $17.27 \%$ (GO-L x GN-01), with average heterosis of $0.248 \mathrm{t} \mathrm{ha}^{-1}$ or $3.75 \%$. Most crosses exhibited heterosis lower than $10 \%$, following a similar pattern observed by Paterniani (1980), Beck et al. (1990), Crossa et al. (1990b), Vasal et al. (1992), and Rezende \& Souza Jr. (2000), who found heterosis expression of intermediate to low magnitude. High heterosis expression is not expected in crosses between broad base and panmitic populations such as pools, synthetics and composites where most of the loci controlling the trait, have intermediate allele frequencies with low proportion of fixed alleles at frequencies 0 or 1 (Miranda Filho, 1999). Therefore, since heterosis is a function of the difference between allele frequencies, most loci contribute little for the heterosis expression even under a high expression of dominant gene action. On the other hand, some authors (Paterniani \& Lonnquist, 1963; Wellhausen, 1965; Paterniani, 1968; Castro et al., 1968; Crossa et al., 1990a) have found high expression of heterosis in crosses, mainly when dealing with old races that have been maintained through small population size during many years. In fact, in populations with such a structure, many loci have fixed alleles or highly contrasting allele frequencies, thus contributing to a high expression of heterosis. Such an effect also happens when the parental population is submitted to some level of inbreeding and the inbreeding depression is recovered in the cross. Miranda Filho (1999) considered that the cross between two non-inbred populations exhibit an heterosis symbolized by $h_{0}$. When crossing two inbred populations with an average inbreeding depression of $\overline{\mathrm{I}}$, then the observed heterosis is $h_{1}=h_{0}+\bar{I}$. When dealing with broad base populations in equilibrium, heterosis without inbreeding $\left(\mathrm{h}_{0}\right)$ should be not more than $20 \%$ in most of cases.

\section{REFERENCES}

BECK, D.L.; VASAL, S.K.; CROSSA, J. Heterosis and combining ability of CIMMYT's tropical early and intermediate maturity maize germoplasm. Maydica, v.35, p.279-285, 1990.

CASTRO, M.; GARDNER, C.O.; LONNQUIST, J.H. Cumulative gene effects and the nature of heterosis in maize crosses involving genetically diverse races. Crop Science, v.8, p.97-101, 1968.

CROSSA, J.; GARDNER, C.O.; MUMM, R.F. Heterosis among population of maize (Zea mays L.) with different levels of exotic germoplasm. Theoretical and Applied Genetics, v.73, p. 445-450, 1987.

CROSSA, J.; TABA, S.; WELLHAUSEN, E.J. Heterotic pattern among Mexican races of maize. Crop Science, v.30, p. 1182-1190, 1990a.

CROSSA, J; VASAL, S.K.; BECK, D.L. Combining ability study in diallel crosses of CIMMYT's tropical late yellow maize germplasm. Maydica, v.35, p. $273-278,1990 b$.

FALCONER, D.S.; MACKAY, T.F.C. Introduction to quantitative genetics. 4.ed. Longman, 1996. 462p.
GARDNER, C.O.; EBERHART, S.A. Analysis and interpretation of the variety cross diallel and related populations. Biometrics, v.22, p.439452,1966

HALLAUER, A.L. Methods used in developing maize inbreds. Maydica, v.35, p.1-16, 1990.

HALLAUER, A. R.; MIRANDA FILHO, J.B. Quantitative genetics in maize breeding. 2.ed. Ames: Iowa State University Press, 1995. 468p.

HOEGEMEYER, T.C.; HALLAUER, A.R. Selection among and within fullsib families to develop single-crosses of maize. Crop Science, v.16, p.76-81, 1976 .

MARTINS, C.S.; MIRANDA FILHO, J.B. Evaluation of inbred lines from two maize (Zea mays L.) brachytic populations. Brazilian Journal Genetics, v.20, p.265-273, 1997.

MIRANDA FILHO, J.B. Cruzamentos dialélicos e síntese de compostos com ênfase na produtividade e no porte da planta. Piracicaba: USP/ ESALQ, 1974. 116p. (Tese-Doutorado)

MIRANDA FILHO, J.B. Inbreeding Depression and Heterosis. In: COORS, J.G.; PANDEY, S. Genetics and exploitation of heterosis in crops; proceedings. Mexico, 1997. Madison: SSSA, ASA, CSSA, 1999. p.6980.

MIRANDA FILHO, J.B.; CHAVES, L.J. Procedures for selecting composites based on prediction methods. Theoretical and Applied Genetics, v.81, p.265-271, 1991.

NASS, L.L.; MIRANDA FILHO, J.B. Synthesis of new composites of maize (Zea mays L.) for population improvement in Brazil. In: REUNIÓN LATINOAMERICANA DEL MAÍZ, 18., Sete Lagoas, 1999. Sete Lagoas: Embrapa Milho e Sorgo, 1999. p. 309-318.

PANDEY, S.; CEBALLOS, H.; MAGNAVACA, R.; BAHIA FILHO, A.F.C.; DUQUE-VARGAS, J.; VINASCO, L. E. Genetics of tolerance to soil acidity in tropical maize. Crop Science, v.34, p.1511-1514, 1994.

PATERNIANI, E. Cruzamentos interraciais de milho. Relatório Científico Instituto de Genética, ESALQ/USP, v.2, p.108-110, 1968.

PATERNIANI, E. Heterosis in intervarietal crosses of maize (Zea mays L.) and their advanced generations. Brazilian Journal Genetics, v.3, p.235$249,1980$.

PATERNIANI, E.; LONNQUIST, J.H. Heterosis in interracial crosses of corn. Crop Science, v.3, p.504-507, 1963.

PÉREZ-VELÁSQUEZ, J.C.; CEVALLOS, H.; PANDEY, S.; DÍAZAMARIS, C. Analysis of diallel crosses among Colombian landraces and improved populations of maize. Crop Science, v.35, p.572-578, 1995.

REZENDE, G.S.P.; SOUZA JR., C.L. A reciprocal recurrent selection procedure outlined to integrate hybrid breeding programs in maize. Journal of Genetics \& Breeding, v.54, p.57-66, 2000.

SHULL, G.H. Beginnings of the heterosis concept. In: GOWEN, J.W. (Ed.) Heterosis: a record of researches directed toward explaining and utilizing the vigor of hybrids. Ames: Iowa State College Press, 1952. p.14-48.

SILVA, R.M. Valor genético e potencial heterótico de populações de milho (Zea mays L.). Piracicaba: USP/ESALQ, 2001. 121p. (Tese-Doutorado)

STANGLAND, G.R.; RUSSEL, W.A.; SMITH, O.S. Evaluation of the performance and combining ability of selected lines derived from improved maize populations. Crop Science, v.23, p.647-651, 1983.

VASAL, S. K.; SRINIVASAN, G.; BECK, D.L.; CROSSA, J.; PANDEY, S.; DE LEON, S. Heterosis and combining ability of CIMMYT's tropical late white maize germplasm. Maydica, v.37, p.217-223, 1992.

VENCOVSKY, R.; BARRIGA, P. Genética biométrica no fitomelhoramento. Ribeirão Preto: Sociedade Brasileira de Genética, 1992. $496 \mathrm{p}$

WELLHAUSEN, E.J. Exotic germplasm for improvement of corn belt maize. In: ANNUAL HYBRID AND CORN INDUSTRY-RESEARCH CONFERENCE, 20., Chicago, 1965. Proceedings. Washington: American Seed Trade Association, 1965. p.31-45.

Received July 11, 2001

Accepted April 11, 2003 